\title{
Sustainable Agroforestry Systems for Livelihood Security and their Economic Appraisal in Indian Himalayas
}

\author{
R.P. Yadav ${ }^{31}$, B. Gupta ${ }^{2}$, P.L. Bhutia ${ }^{3}$ and J.K. Bisht ${ }^{1}$ \\ ${ }^{1}$ Crop Production Division, ICAR-Vivekananda Parvatiya Krishi Anusandhan Sansthan, Almora-263601, India \\ ${ }^{2}$ Department of Silviculture and Agroforestry, College of Foretsry, Dr. Y S Parmar University of Horticulture and Forestry-Nauni, \\ Solan-173230, India \\ ${ }^{3}$ College of Forestry, Dr. Y S Parmar University of Horticulture and Forestry-Nauni, Solan-173230, India
}

*Corresponding author: rams34052@gmail.com

\begin{abstract}
Sustainable indigenous agroforestry systems are mainstay of rural agrarian economy coupled with livestock rearing in mountains of Himalayas. A 2B4D6-watershed was selected in Central Himalayas to investigate economic returns from agriculture based agroforestry systems. A detailed structured analysis revealed four types of agriculture based agroforestry systems are prevalent in the 2B4D6-watershed of Indian Central Himalaya. These agroforestry systems are profitable to farmers and can obtain more than two-fold returns from agriculture based agroforestry systems. The net return from these systems decreased in the order: Agrihorticulture $>$ Agrihortisilviculture $>$ Agrisilvihorticulture $>$ Agrisilviculture. The highest benefit cost ratio from agroforestry systems was obtained at higher elevation $\mathrm{E}_{5}$ and it decreased with decrease in elevations in the order: $E_{4}>E_{3}>E_{2}>E_{1}$. Thus, we conclude that agroforestry systems are not only sustainable but also are imperative for livelihood security of local inhabitants of Indian Central Himalayas.
\end{abstract}

Keywords: Agroforestry; Benefit-cost ratio; Economic returns; Himalayas; Livelihood; Sustainability

Indian Himalaya covers $\sim 16.2 \%$ of India's total geographical area, and is divided into western, central and eastern Himalaya. It is mountainous and is characterized by vertical zonation into elevational belts with gradual change in climate (Korner 2007; Ghimire 2010; Paudel and Vetaas 2014), that contribute to alterations in biological diversity along elevation (Cantlon 1953; Pook and Moore 1966). Himalayan ecosystems are complex, with fragile environment, rugged terrain, unique topography and sensitivity to regional and global changes (Palni et al. 1998), therefore the region exhibits varied land use patterns and drastic changes in the landscape ecology in short distances. The vegetation distribution pattern, communities, and population dynamics are most significant ecological attributes of any area (Gairola et al. 2008). Agroforestry systems in the Himalaya are backbone of hill agrarian community for livelihood security
(Yadav et al. 2016). Various forms of agroforestry such as improved fallows beside maintenance of soil fertility also improve on farm environment quality (Kuntashula and Mungatana 2015), carbon sequestration (Cacho et al. 2005; Yadav et al. 2017) and economic sustainability (Kitti et al. 2009). Hence, there is enough scope in Himalayan agroforestry research for economic benefit to community and diverse ecosystem services in the context of global climate change.

The social factors play direct and indirect roles in land use management decisions including tillage, plant residue management, manure usage and fertilizer application (FAO 2004; Nair et al. 2010), which in turn affect the biomass and sequestration of $C$ in land use systems. Social factors such as farmer's economic and educational status (Anjichi et al. 2007; Matata et al. 2010), demography, social connections, culture, and resource availability are 
important to understand why and how farmers select certain management practices (Seabrook et al. 2008). Availability of resources such as raw materials, labor and domestic animals also influence farmers' decision to adopt specific practices (Williams 1999).

Agricultural decisions made by individuals (or farmers) are often influenced by their economic opportunities (Lambin et al. 2001). The magnitude of social factors influence on the land use management practices depends largely on the economic importance of the system. In commercial land use systems, in which management decisions are made with the goal of higher production and profit maximization, the influence of cultural, demographic, and social factors are seldom considered. The management of land use systems, which are practiced predominantly in smallholder farms, however, is influenced by a number of social factors other than economics.

In Himlayas human habitation is found up to an altitude of $3500 \mathrm{~m}$ above mean sea level; however, the zone between 1200 - $2000 \mathrm{~m}$ is densely populated. In the study area $69.45 \%$ of its total population lives in rural areas (GOI 2011) whose economy is dependent on agriculture and allied sector. Out of total reported area, only $14.02 \%$ is under cultivation and more than $55.0 \%$ of the cultivated land in the state is rainfed. The state supports about 4.75 million livestock population. Over exploitation of natural resources by the inhabitants for subsistence living, far beyond their capacity to rejuvenate, has led to their degradation.

Almora is a hill region in Uttarakhand and here the agrarian economy is entirely dependent on income or services from natural resources. Hence, the present investigation was undertaken to study economic returns and profitability in detail of agricultural based agroforestry systems which are important for rural economy. For this purpose agroforestry systems were studied with the following objectives:

(i) economic returns from agroforestry systems,

(ii) correlation among economic parameters with elevation and (iii) benefit-cost ratio of agroforestry systems as well as along elevation in Himalayas.

\section{MATERIALS AND METHODS}

\section{Study area}

The present investigation was carried out in 2B4D6- watershed (The nomenclature given by Soil and Land Use Survey of India, New Delhi) in Almora district of Uttarakhand state is located in Central Himalaya. This watershed is bounded between latitude $29^{\circ} 24^{\prime}$ to $29^{\circ} 52^{\prime} \mathrm{N}$ and longitude $79^{\circ} 30^{\prime}$ to $79^{\circ} 51^{\prime}$ E (Fig. 1) covering an approximately 78,483 hectare area. The general terrain of this watershed is mountainous with altitudinal range from $800 \mathrm{~m}$ to above 2250 meter above sea level (masl). Government of India has delineated 21 subwatersheds and 172 micro-watersheds in it.

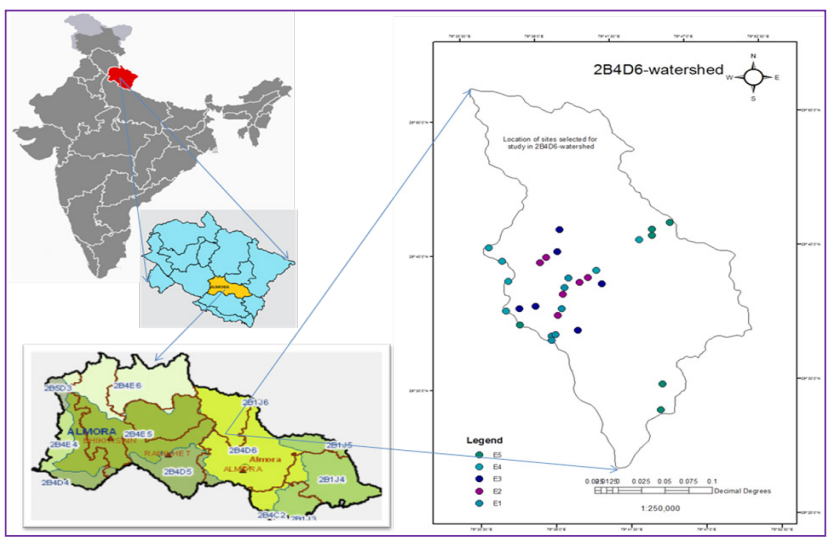

Fig. 1: Location of 2B4D6-watershed in Almora district of Uttarakhand

\section{Climate}

Climate in this watershed is sub-tropical in lower areas and wet-temperate in upper areas. Annual precipitation varies from $1000 \mathrm{~mm}$ in Hawalbagh to $2150 \mathrm{~mm}$ in Nainital. However, the mean annual precipitation in the area is around $1350 \mathrm{~mm}$. The snow fall is a normal feature in areas above 1800 $\mathrm{m}$. The region has three distinct seasons, viz. rainy (July-September), winter (November-February) and summer (April-June). The major proportion (around $60 \%$ ) of annual precipitation is received during rainy season.

The meteorological record of the years 2001 to 2015 for Hawalbagh in Almora, a part of 2B4D6watershed, revealed that mean annual maximum air temperature in this area varied between 25.64 to $26.79^{\circ} \mathrm{C}$, mean annual minimum air temperature fluctuated between 9.42 to $10.78^{\circ} \mathrm{C}$ and mean annual air temperature hovered between 17.54 to $18.79^{\circ} \mathrm{C}$ (Fig. 2). Annual rainfall in the area ranged from $667.90 \mathrm{~mm}$ to $1369.50 \mathrm{~mm}$ and the mean annual relative humidity fluctuated from $66.44 \%$ to $73.73 \%$. 


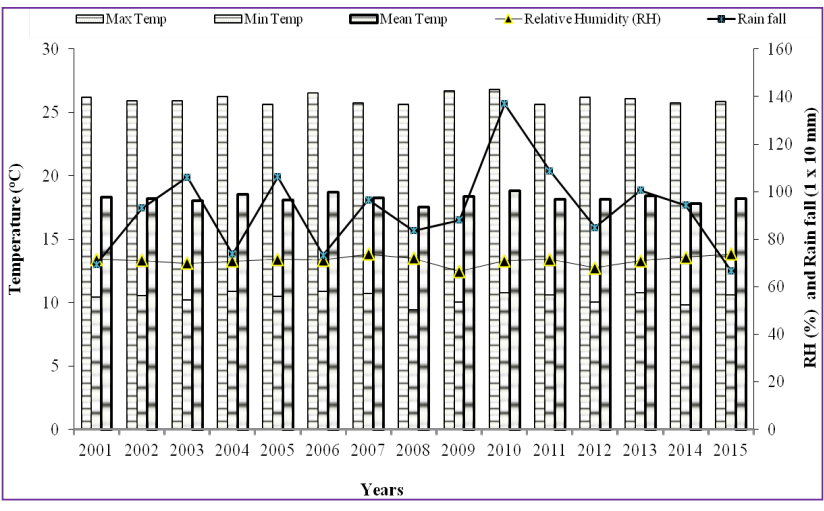

Fig. 2: Meteorological record of 2B4D6-watershed in Central Himalaya

\section{Selection of experimental sites}

The 2B4D6-watershed selected for the present study was stratified into five elevation zones viz., $\mathrm{E}_{1}=<1100 \mathrm{~m}, \mathrm{E}_{2}=1101-1400 \mathrm{~m}, \mathrm{E}_{3}=1401-1700$ $\mathrm{m}, \mathrm{E}_{4}=1701-2000 \mathrm{~m}$ and $\mathrm{E}_{5}=>2000 \mathrm{~m}$. In each elevation zone an extensive survey was done. Six representative experimental sites, each of around 1 $\mathrm{km}^{2}$, were selected in all the elevation zones. The present study entailed only those land uses which are directly related to rural and agrarian economy. Thus, in each experimental site emphasis was given on economic analysis of agriculture based agroforestry systems. The classification criteria as given by Nair (1985) were followed to identify and classify agroforestry systems.

\section{Economic analysis}

The economic return in different agroforestry systems was calculated according to (CACP, 2016) by determining the following:

(i) Production Cost (Input): Cost of cultivation is the total amount of expenditure such as ploughing, seed, labour (man days), fertilizer, irrigation, transportation etc. done on production of crops.

(ii) Gross return: The utilizable biomass i.e., grain, straw/stover, fruit, fodder and fuel wood from each functional unit in a system was taken for estimating the total return from the system.

(iii) Net returns: Production cost deducted from gross return to obtain net return as given below:

Net Return $=$ Gross return - production cost

\section{Statistical analysis}

Variation in parameters like, gross returns, total expenses, net returns and benefit-cost ratio in different systems and along the elevation was compared by using analysis of variance, correlation etc. by using SPSS and JMP software.

\section{RESULTS AND DISCUSSION}

\section{Gross return}

Among agroforestry systems (Table 1) significantly higher gross return was obtained from AH (₹ 301823.93 ha $^{-1} \mathrm{yr}^{-1}$ ) followed by AHS (₹ 279801.14 ha- $^{-}$ ${ }^{\mathrm{l}} \mathrm{yr}^{-1}$ ), ASH (₹ 160987.24 ha- $\mathrm{yr}^{-1}$ ) and AS (₹ 104574.55 ha-1 $\mathrm{yr}^{-1}$ ).

Table 1: Economic values ( $₹$ ha $\left.^{-1} \mathrm{yr}^{-1}\right)$ of agriculture based agroforestry systems

\begin{tabular}{|c|c|c|c|c|}
\hline \multirow[b]{2}{*}{$\begin{array}{l}\text { Systems } \\
\text { (S) }\end{array}$} & \multicolumn{4}{|c|}{ Economic value $\left(₹ \mathrm{ha}^{-1} \mathrm{yr}^{-1}\right)$} \\
\hline & $\begin{array}{l}\text { Gross } \\
\text { return }\end{array}$ & $\begin{array}{c}\text { Total } \\
\text { expenses }\end{array}$ & Net return & $\begin{array}{c}\text { Benefit: } \\
\text { Cost ratio }\end{array}$ \\
\hline AS & $104574.55 \mathrm{c}$ & $50599.15 \mathrm{c}$ & $53975.41 \mathrm{~d}$ & $2.07 \mathrm{~d}$ \\
\hline $\mathrm{AH}$ & $301823.98 a$ & $119660.52 \mathrm{a}$ & $182163.45 \mathrm{a}$ & $2.53 \mathrm{a}$ \\
\hline AHS & $279801.14 \mathrm{a}$ & $115855.69 a$ & $163945.45 \mathrm{~b}$ & $2.44 \mathrm{~b}$ \\
\hline ASH & $160987.24 \mathrm{~b}$ & $69280.33 \mathrm{~b}$ & $91706.90 \mathrm{c}$ & $2.32 \mathrm{c}$ \\
\hline $\begin{array}{l}\text { LSD } \\
(<0.01)\end{array}$ & 40799.15 & 17579.7 & 17983.7 & 0.08 \\
\hline
\end{tabular}

Where, $S=$ Systems, LSD = Least significant difference; Different successive letters suffixing the numbers in the columns denote significant difference; $A S=$ Agrisilviculture, $A H=$ Agrihorticulture, AHS $=$ Agrihortisilviculture, ASH $=$ Agrisilvihorticulture .

However, the gross return from $\mathrm{AH}$ was at par with gross return from AHS. The average gross return $\left(₹\right.$ ha $\left.^{-1} \mathrm{yr}^{-1}\right)$ from agriculture based agroforestry systems did not vary significantly along the elevation (Fig. 3).

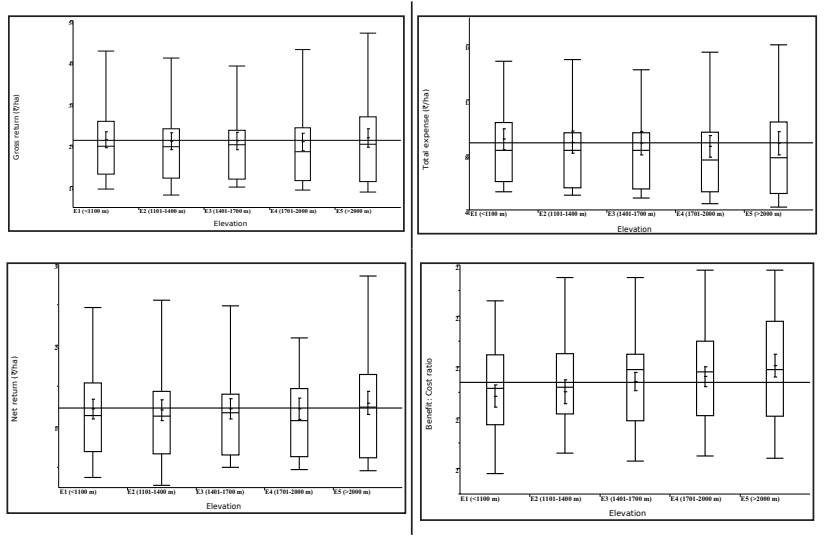

Fig. 3: Gross return, total expense, net return and benefit: cost ratio of agriculture based agroforestry systems along elevation gradient 
The highest ( $217616.84 \mathrm{~F}^{\mathrm{ha}} \mathrm{yr}^{-1} \mathrm{yr}^{-1}$ ) gross return from these systems was recorded at elevation $E_{5}$ and lowest at elevation $\mathrm{E}_{4}\left(208015.62 \mathrm{~F} \mathrm{ha}^{-1} \mathrm{yr}^{-1}\right)$.

The interaction between elevations and systems (Fig. 4) on gross returns from agroforestry systems was insignificant. Highest gross return was obtained from $\mathrm{AH}$ (₹ $320788.56 \mathrm{ha}^{-1} \mathrm{yr}^{-1}$ ) at elevation $\mathrm{E}_{5}$ and lowest gross return was observed from AS (₹ $97868.55 \mathrm{ha}^{-1} \mathrm{yr}^{-1}$ ) at elevation $\mathrm{E}_{3}$.

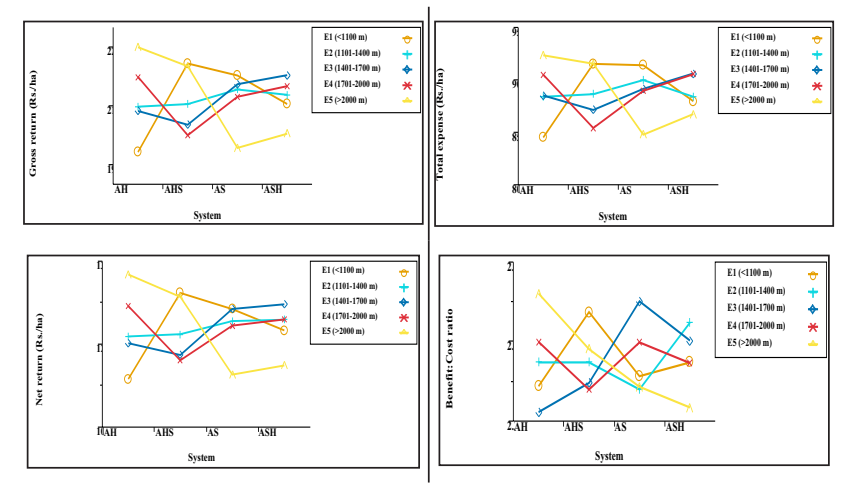

Fig. 4: Effect of interaction between elevation and agriculture based agroforestry systems $(\mathrm{E} \times \mathrm{S})$ on gross return, total expenses, net return and benefit cost ratio

\section{Total expenses}

A perusal of data presented in Table 1 revealed that significantly higher average total expenses (₹ 119660.52 ha $^{-1} \mathrm{yr}^{-1}$ ) incurred in $\mathrm{AH}$ whereas in other agriculture based agroforestry systems total expenditure decreased in the order: AHS (₹ $\left.115855.69 \mathrm{ha}^{-1} \mathrm{yr}^{-1}\right)>$ ASH $\left(₹ 69280.33 \mathrm{ha}^{-1} \mathrm{yr}^{-1}\right)>$ AS (₹ 50599.15 ha $^{-1} \mathrm{yr}^{-1}$ ). However, total expenses incurred in $\mathrm{AH}$ was at par with AHS. The total expenditure incurred in systems (Fig. 3) did not vary significantly along the elevations and highest total expenditure ( $₹ 91526.70 \mathrm{ha}^{-1} \mathrm{yr}^{-1}$ ) was recorded in agroforestry systems at elevation $\mathrm{E}_{1}$ and lowest at elevations $\mathrm{E}_{4}$ ( $₹ 86310.28$ ha $^{-1} \mathrm{yr}^{-1}$ ).

The interaction between systems and elevations on total expenditure was non-significant. Highest expenditure of ₹ $122843.41 \mathrm{ha}^{-1} \mathrm{yr}^{-1}$ was incurred in agrihorticulure system $(\mathrm{AH})$ at elevation $\mathrm{E}_{5^{\prime}}$ whereas lowest expenditure of ₹ $46210.38 \mathrm{ha}^{-1} \mathrm{yr}^{-1}$ was recorded in agrisilviculture system (AS), also at elevation $\mathrm{E}_{5}$ (Fig. 4).

\section{Net return}

Data presented in the Table 1 revealed that among agriculture based agroforestry systems highest net return ₹ 182163.45 ha $^{-1} \mathrm{yr}^{-1}$ was obtained from agrihorticulture system $(\mathrm{AH})$, which was significantly higher than any other system whereas it ₹ $163945.45 \mathrm{ha}^{-1} \mathrm{yr}^{-1}$ from AHS, ₹ 91706.90 ha $^{-1}$ $\mathrm{yr}^{-1}$ from ASH and ₹ $53975.41 \mathrm{ha}^{-1} \mathrm{yr}^{-1}$ from AS. Net return obtained from systems at different elevations did not vary significantly (Fig. 3). However, highest net return ( $₹ 129079.82$ ha $^{-1} \mathrm{yr}^{-1}$ ) from agroforestry systems was obtained at elevation $\mathrm{E}_{5}$ and lowest at elevation $\mathrm{E}_{2}$ (₹ 120409.46).

The effect of interaction between elevations and systems on net returns was non-significant (Fig. 4). Highest net return ( $₹ 197945.15 \mathrm{ha}^{-1} \mathrm{yr}^{-1}$ ) was obtained at elevation $\mathrm{E}_{5}$ from agrihorticulture system (AH) and lowest net return (₹ 51658.17 ha $^{-1}$ $\mathrm{yr}^{-1}$ ) was obtained from agrisilviculture system (AS) also at elevation $\mathrm{E}_{5}$ (Fig. 4).

\section{Benefit-Cost ratio}

A perusal of data in Table 1 revealed that difference in benefit cost ratio calculated for different agriculture based agroforestry systems was significant. Among agroforestry systems average benefit-cost ratio of 2.53 calculated for agrihorticulture system $(\mathrm{AH})$ was significantly higher and it decreased in the order: AHS (2.44) > ASH (2.32) > AS (2.07).

It was recorded that variation in mean benefit-cost ratio of agroforestry systems along the elevation was non-significant (Fig. 3). However, the highest benefit cost ratio of 2.40 in agroforestry systems was obtained at elevation $\mathrm{E}_{5}$, and it decreased with decrease in elevations in the order: $\mathrm{E}_{4}$ (2.36) $>\mathrm{E}_{3}(2.34)>\mathrm{E}_{2}(2.30)>\mathrm{E}_{1}$ (2.28). The interaction of systems and elevations for benefit-cost ratio was non-significant. Highest benefit-cost ratio (2.63) was recorded in agrihorticulture $(\mathrm{AH})$ at elevation $\mathrm{E}_{5}$ and lowest benefit-cost ratio (2.01) in agrisilviculture (AS) at elevations $\mathrm{E}_{1}$ and $\mathrm{E}_{2}$ (Fig. 4).

Among different agriculture based agroforestry systems, gross and net returns (Table 1) were higher from agrihorticulture $(\mathrm{AH})$ and agrihortisilviculture (AHS) as compared to agrisilviculture (AS) and agrisilvihorticulture (ASH). It is pertinent to mention here that the arrangement and management of components, output and their market value are the major factors which govern the economic returns from agroforestry systems. Vegetable crops like, tomato, cabbage, capsicum, garlic, cauliflower 
and pea cultivation and sale of fruits generate more income to the farmers. Thus returns were highest from agrihorticulture system. The returns from agrihortisilviculture, agrisilvihorticulture and agrisilviculture were slightly less, than agrihorticulture because in these systems cereal crops are grown in larger area. Very low returns were obtained from agrisilviculture system as only cereal crops were grown in this system which fetches less capital from market due to low market value than cash crops beside less production due to rainfed farming. Total expenses and net returns were positively correlated with elevation though it was very weak relationship (Fig. 5A). Whereas, critical view of Fig. $5 \mathrm{~B}$ revealed a strong and positive correlation $\left(R^{2}=0.93\right)$ of net return $(₹ / h a)$ with total expense ( $₹ /$ ha) from agriculture based agroforestry systems.
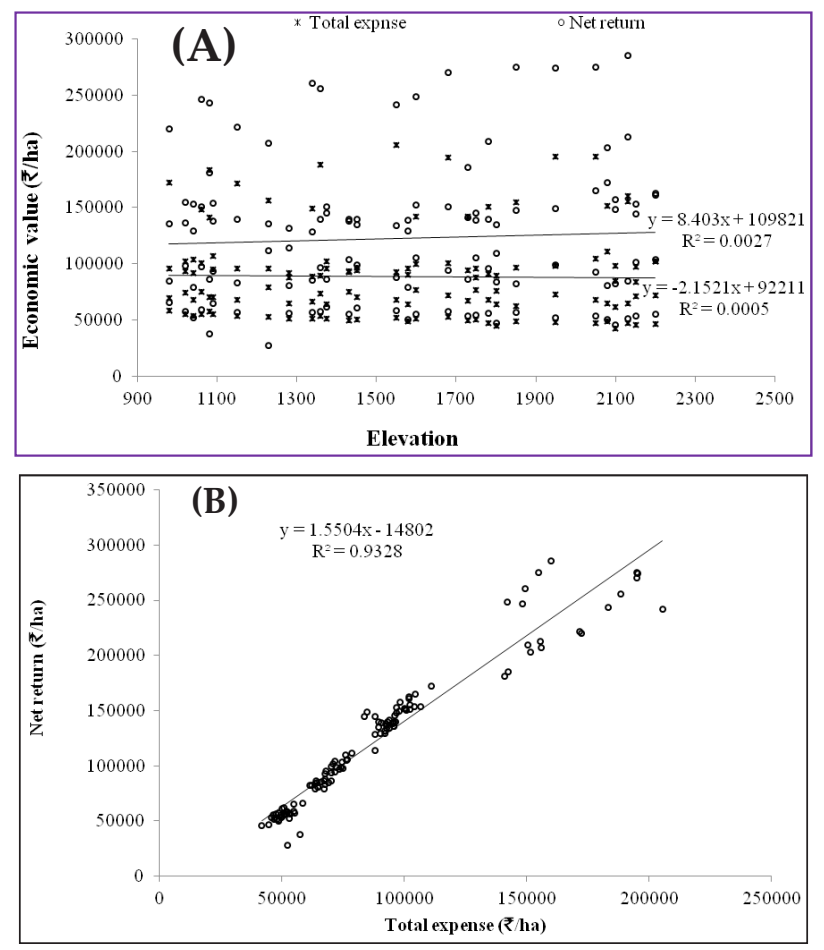

Fig. 5: Correlation of economic value with elevation (A) and net return with total expense (B) of agriculture based agroforestry systems

Many workers have reported higher returns from agrihorticulture systems in Himalaya. Rajput (2010) reported that cultivation of apple and vegetable crops in agrihorticulture systems, in Kullu valley of Himachal Pradesh was responsible for higher returns to the tune of ₹ 7.32 lakhs/ha/year. Tomar and Bhatt (2004), contended that when peach is intercropped with rice obtained higher net monetary benefit ( $₹ 40,404$ ), as compared to rice cultivation with guava or Assam lemon (₹ 27,087). Sood (1999) also reported that in comparison to sole crop, agrihorticulture system provides more return. Prakash (2015) reported Grewia based agroforestry (Grewia + Godetia grandiflora + Gomphrena globosa) has higher gross (₹ 10.19-10.46 lakh/ha) and net returns (₹ 4.08-4.25 lakh/ha) as compared to sole crop (₹ 3.34-9.39 lakh/ha). Rani et al. (2015) reported gross return per acre with wheat in poplar ( $₹ 25,760$ to 26,525 ) and hard pear ( $₹ 24,970$ to 29,300 ) based agroforestry system. Sanwal et al. (2016a, b) obtained net return from Pinus based silvimedicinal system (Pinus roxburghii + Solanum khasianum) from 2610 to 9477 ₹/ha and in another study net return to the tune of (Pinus roxburghii + Mucuna pruriens) 8685 to 14643 ₹/ha.

Benefit-cost ratio (Table 1) of the agriculture based agroforestry systems in the present study decreased in the order: agrihorticulture (2.53) > agrihortisilviculture (2.44) > agrisilviculture (2.32) $>$ agrisilviculture (2.07). Benefit-cost ratio showed a positive but weak correlation with elevation (Fig. 6A). However benefit-cost ratio was shown moderate positive correlation $\left(R^{2}=0.46\right)$ with net return (Fig. 6B).
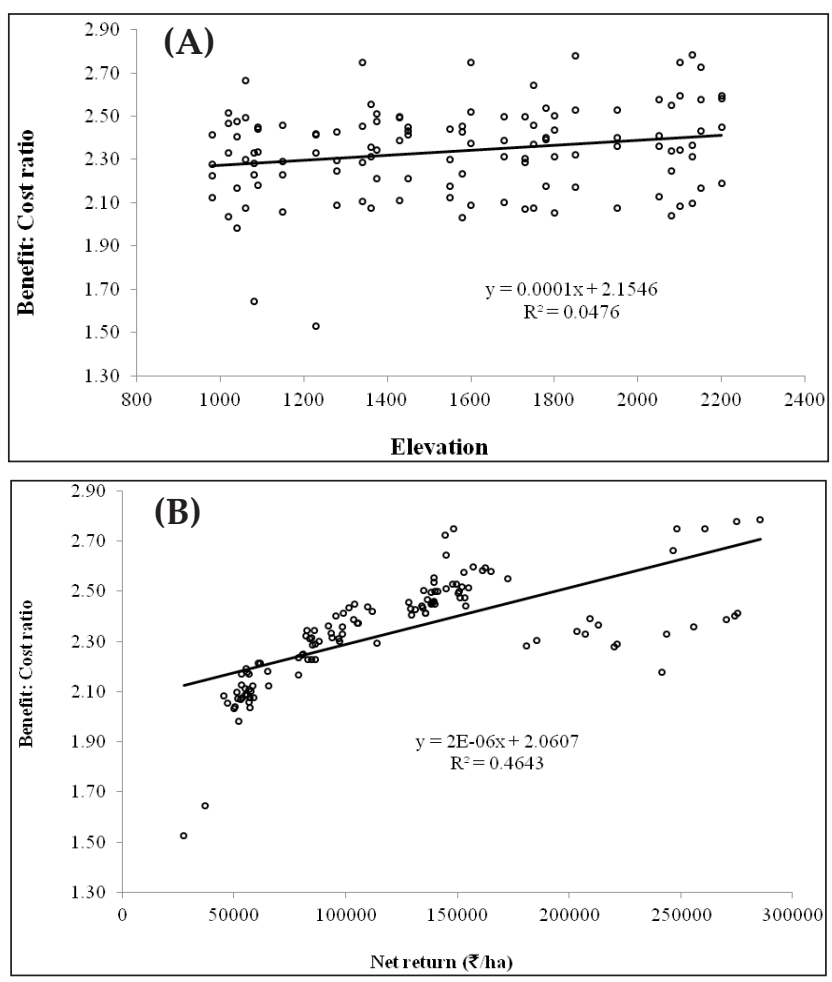

Fig. 6: Correlation of Benefit: Cost ratio with elevation (A) and benefit: cost ratio with net return (B) of agriculture based agroforestry systems 
Benefit-cost ratio of 2.94 for agrihorticulture in Kullu valley of Himachal Pradesh was reported by Rajput (2010). Verma et al. (2002) reported benefit cost ratio ranging from 1.99 to 2.34 for agrisilvihorticulture systems in Solan (HP). The benefit-cost ratio of agroforestry systems in the range of 1.87-5.7 have been reported by many researchers like Dhyani et al. (1996) for sericulture based agroforestry systems in Meghalaya; Kumar et al. (2002) for hortipastoral systems at Jhansi; Bhatt and Mishra (2003) for Assam lemon and Guava based agroforestry systems in Meghalaya and Sharma (2007) for cardamom based agroforestry in Sikkim. Benefit cost ratio 3.63 3.78 as compared 3.53 in open for flower crops (Callistephus chinensis + Dianthus barbatus) grown for the seed production under the Grewia based agroforestry system was reported by Prakash (2015). Rani et al. (2015) reported benefit-cost ratio as 2.53 after five years under agroforestry (wheat + poplar) as compared to benefit-cost ratio 1.26 to 1.32 of wheat under poplar and 1.19 to 1.57 in wheat with hard pear during initial years of these agroforestry systems. Chauhan et al. (2015) reported benefit-cost ratio in block plantation (3.30) than boundary (1.90) and sole cropping (1.61) of rice-wheat.

\section{CONCLUSION}

The benefit-cost ratio was significantly $(\mathrm{P}<0.05)$ highest of 2.53 in agrihorticulture system $(\mathrm{AH})$ and it decreased in the order: AHS (2.44) > ASH (2.32) $>$ AS (2.07). It was recorded that for managing agriculture based agroforestry systems expenses of ₹ $119660.52 \mathrm{ha}^{-1} \mathrm{yr}^{-1}$ incurred in AH, ₹ $115855.69 \mathrm{ha}^{-1}$ $\mathrm{yr}^{-1}$ in AHS, ₹ $69280.33 \mathrm{ha}^{-1} \mathrm{yr}^{-1} \mathrm{ASH}$ and ₹ 50599.15 $\mathrm{ha}^{-1} \mathrm{yr}^{-1}$ in AS. Maximum gross return of ₹ 301823.93 $\mathrm{ha}^{-1} \mathrm{yr}^{-1}$ was obtained from $\mathrm{AH}$, while gross return from AHS was ₹ $279801.14 \mathrm{ha}^{-1} \mathrm{yr}^{-1}$, from ASH was ₹ $160987.24 \mathrm{ha}^{-1} \mathrm{yr}^{-1}$ and from AS was ₹ 104574.55 $\mathrm{ha}^{-1} \mathrm{yr}^{-1}$. Thus, net returns of ₹ $182163.45 \mathrm{ha}^{-1} \mathrm{yr}^{-1}$ was obtained from agrihorticulture system $(\mathrm{AH})$, ₹ $163945.45 \mathrm{ha}^{-1} \mathrm{yr}^{-1}$ from AHS, ₹ $91706.90 \mathrm{ha}^{-1} \mathrm{yr}^{-1}$ from ASH and ₹ $53975.41 \mathrm{ha}^{-1} \mathrm{yr}^{-1} \mathrm{AS}$. Among agriculture based agroforestry systems mean benefit-cost ratio was significantly high (2.53) in agrihorticulture system $(\mathrm{AH})$ than other systems.

\section{REFERENCES}

Anjichi, V.E., Mauyo, L.W. and Kipsat, M.J. 2007. The effect of socioeconomic factors on a farmer's decision to adopt farm soil conservation measures: an application of multivariate logistic analysis in Butere/Mumias district Kenya. In: Advances in integrated soil fertility management in Sub-Saharan Africa: challenges and opportunities. Bationo A, Waswa B, Kihara J and Kimetu J (eds.). Springer, Dordrecht, pp. 915-920.

Bhatt, B.P. and Mishra, L.K. 2003. Production potential and cost-benefit analysis of agrihorticulture agroforestry systems in Northeast India, Journal of Sustainable Agriculture, 22(2): 99-108.

Cacho, O. Marshall, G.R. and Milne, M. 2005. Transaction and abatement costs of carbon-sink projects in developing countries, Environment and Development Economics, 10(5): 597-614.

CACP (Reports of the Commission for Agricultural Costs and Prices). 2016. Department of Agriculture and Cooperation, Ministry of Agriculture, Government of India (Controller of Publication, Delhi- 2016).

Cantlon, J. 1953. Vegetation and microclimates of north and south slopes of Cushetunk Mountain, New Jersey, Ecological Monograph, 23: 241-270.

Chauhan, S.K., Sharma, R., Singh, B. and Sharma, S.C. 2015. Biomass production, carbon sequestration and economics of on-farm poplar plantations in Punjab, India, Journal of Applied and Natural Science, 7(1): 452-458.

Dhyani, S.K., Chauhan, D.S., Kumar, D., Kushwaha, R.V. and Lepcha, S.T. 1996. Sericulture-based agroforestry Systems for hilly areas of north-east India, Agroforestry Systems, 34: 247-258.

FAO (Food and Agricultural Organisation). 2004. Carbon sequestration in dryland soil. In: World Soil Resources Reports 102, FAO, Rome. Available at http://www.fao. org/docrep/007/y5738e/y5738e0d.htm.

Gairola, S., Rawal, R.S. and Todaria, N.P. 2008. Forest vegetation patterns along an altitudinal gradient in subalpine zone of west Himalaya, India, African Journal of Plant Science, 2: 42-48.

Ghimire, B.K., Mainali, K.P., Choudhary, R.P. and Ghimeray, A.K. 2010. Regeneration of Pinus wallichiana AB jackson in a trans-Himalayan dry valley of north-central Nepal, Himalayan Journal of Science, 6: 19-26.

GOI [Government of India]. 2011. Government of India, Ministry of Home Afairs. http://censusindia.gov.in/2011prov-results/datafiles/uttarakhand/pptfigures pressrel. pdf

Kitti, M., Heikkila, J. and Huhtala, A. 2009. Fair' policies for the coffee trade - protecting people or biodiversity? Environment and Development Economics, 14(6): 739-758.

Korner, C. 2007. The use of altitude in ecological research, Trends in Ecology and Evolution, 22(11): 569-574.

Kumar, S., Kumar, S., Baig, M.J., Chaubey, B.K. and Sharma, R.K. 2002. Effect of nitrogen on productivity of Aonla based hortipastoral system. Indian Journal of Agroforestry, 4(2): 94-97.

Kuntashula, E. and Mungatana, E. 2015. Estimating the causal effect of improved fallows on environmental services provision under farmers' field conditions in Chongwe, 
Zambia. Environment and Development Economics, 20(1): 80-100.

Lambin, E.F., Turner, B.L., Geist, H.J., Agbola, S.B., Angelson, A., Bruce, J.W., Coomes, O.T., Dirzo, R., Fischer, G., Folke, C., George, P.S., Homewood, K., Imbernon, J., Leemans, R., Li, X., Moran, E.F., Mortimer, M., Ramakrishnan, P.S., Richards, J.F., Skanes, H., Steffe, W., Stone, G.D., Svedin, U., Veldkamp, T.A., Vogel. C. and Xu, J. 2001. The causes of land- use and land- cover change: moving beyond the myths. Global Environmental Change, 11: 261-269.

Matata, P.Z., Ajay, O.C., Oduol, P.A. and Agumya, A. 2010. Socio-economic factors influencing adoption of improved fallow practices among smallholder farmers in western Tanzania. African Journal of Agricultural Research, 5(8): 818-823.

Nair, P.K.R., Nair, V.D., Kumar, B.M. and Showalter, J.M. 2010. Carbon sequestration in agroforestry systems, Advanced Agronomy, 108: 237-307.

Nair, P.K.R. 1985. Classification of agroforestry systems, Agroforestry Systems, 3: 97-128.

Palni, L.M.S., Maikuri, R.K. and Rao, K.S. 1998. Conservation of the Himalayan agroecosystem: issues and priorities. Technical Paper-V in Eco regional Cooperation for Biodiversity Conservation in the Himalaya, United Nation Development Programme, New York, pp. 253-290.

Paudel, S. and Vetaas, O.R. 2014. Effects of topography and land use on woody plant species composition and beta diversity in an arid trans-Himalayan landscape, Nepal, Journal of Mountain Science, 11(5): 1112-1122.

Pook, E. and Moore, C. 1966. The influence of aspect on the composition and structure of dry sclerophyll forest on black mountain Canberra, Australian Journal of Botany, 14: 223-242.

Prakash, P. 2015. Effect of tree spacing and organic manures on growth, flower and seed production of floriculture crops under Grewia optiva Drummond. based agroforestry system. Ph.D. thesis, agroforestry, submitted to Dr. Yashwant Singh Parmar University of Horticulture And Forestry Solan (Nauni) HP - 173230 India, 250pp.

Rajput, B.S. 2010. Bio-economic appraisal and carbon sequestration potential of different land use systems in temperate north-western Himalayas. Ph.D. Thesis. Dr. Y. S. Parmar University of Horticulture and Forestry, Nauni, Solan (H.P.), India. 169 pp.

Rani, S., Rajasekaran, A., Benbi, D.K. and Chauhan, S.K. (2015). Cost benefit analysis and yield performance of agricultural crops under poplar and fruit crop in north western zone of Punjab, India, International Journal of Scientific Research, 4(6): 791-793.
Sanwal, C.S., Kumar, R. and Bhardwaj, S.D. (2016a). Integration of Andrographis paniculata as potential medicinal plant in chir pine (Pinus roxburghii Sarg.) plantation of north-western Himalaya. Scientifica Volume 2016, Article ID 2049532, 7p.

Sanwal, C.S., Kumar, R., Anwar, R., Kakade. V., Kerketta, S. and Bhardwaj, S.D. (2016b). Growth and yield of Solanum khasianum in Pinus roxburghii forest based silvi-medicinal system in mid hills of Indian Himalaya, Forest Ecosystems, 3(19).

Seabrook, L., McAlpine, C. and Fensham, R.J. 2008. What influences farmers to keep trees? A case study from the Brigalow Belt Queensland Australia, Landscape and Urban Planning, 84: 266-281.

Sharma, R., Jianchu, X. and Sharma, G. 2007. Traditional agroforestry in the eastern Himalayan region: land management system supporting ecosystem services, Tropical Ecology, 48(2): 189-200.

Sood, R. 1999. Tree crop interaction studies in agri-horticulture system. M.Sc. Thesis. Dr. Y. S. Parmar University of Horticulture and Forestry, Nauni, Solan, (H.P.), India. 81 p.

Tomar, J.M.S. and Bhatt, B.P. 2004. Studies on horti-agricultural system in a mid-altitude of Meghalaya, Indian Journal of Agroforestry, 6(2): 35-39.

Verma, K.S., Zegeye, M.W. and Kaushal, R. 2002. Growth and yield performance of wheat in agri-horti-silvicultural system of agroforestry in the mid-hills of Himachal Himalayas, Indian Journal of Agroforestry, 4(1): 1-7.

Williams, T.O. 1999. Factors influencing manure application by farmers in semi-arid West Africa, Nutrient Cycling Agroecosystems, 55: 15-22.

Yadav, R.P., Gupta, B., Bhutia, P.L. and Bisht, J.K. 2016. Socioeconomics and sources of livelihood security in Central Himalaya, India: a case study, International Journal of Sustainable Development \& World Ecology, 24(6): 545-553.

Yadav, R.P., Bisht, J.K. and Bhatt, J.C. 2017. Biomass, carbon stock under different production systems in the mid hills of Indian Himalaya, Tropical Ecology, 58(1): 15-21.

One Liner: Among agriculture based agroforestry systems mean net return and benefit-cost ratio was significantly high in agrihorticulture system $(\mathrm{AH})$ than other systems. 
